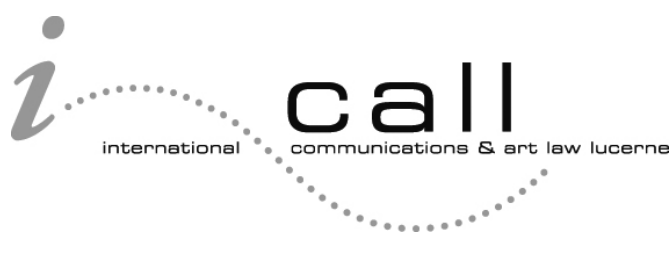

\title{
Institutionalization of Creativity in Traditional Societies and in International Trade Law
}

\author{
Christoph Beat Graber*
}

AUGUST 2010

\begin{abstract}
Modern legal systems were not developed to deal with the modes of creativity and the meanings behind cultural expressions of traditional societies. The protection of creative expressions and knowledge through intellectual property rights has a commoditizing effect, inconsistent with the customary norms of many traditional societies, such that the propertization is offensive. This paper assesses the concept of creativity, from a modern and traditional perspective, and the effect of globalization on Indigenous peoples' views on the trade of their cultural heritage. It then analyzes Indigenous creativity in the realm of international trade law and how WTO law could better serve the interests of Indigenous peoples, with respect to their participation in the international trade of certain aspects of their cultural heritage, and discusses how the UN Declaration on the Rights of Indigenous Peoples may affect such trade.
\end{abstract}

\section{KEY WORDS}

Indigenous peoples, creativity, indigenous heritage, traditional cultural expression, traditional knowledge, institutionalization, proceduralization, international trade law, WTO, TRIPS, GATT, GATS, preferential treatment, UN Declaration on the Rights of Indigenous Peoples

\footnotetext{
* Christoph Beat Graber, PhD, is a Professor of Law and Head of the i-call Research Centre (International Communications and Art Law Lucerne), Faculty of Law, University of Lucerne (Switzerland). This chapter is based on a paper that was presented at the workshop 'Creativity, Law and Entrepreneurship', organised by the University of Wisconsin School of Law, 24 April 2009. The author would like to thank the participants of the workshop as well as Susy Frankel for their comments and Susan Kaplan for editorial assistance.

Contact at christoph-beat.graber@unilu.ch
}

I-CALL WORKING PAPERS are the result of research that takes place through the i-call research centre. The papers have been peer-reviewed.

Suggested Citation: Graber, Christoph Beat (2010), 'Institutionalization of Creativity in Traditional Societies and in International Trade Law', IT-ICH i-call Working Paper No. 01, Lucerne, Switzerland: University of Luzern. 
Published by:

i-call, The Research Centre for International Communications and Art Law at the University of Lucerne

Hofstrasse 9

P.O. Box 7464

6000 Lucerne 7

Switzerland

ISSN 1664-0144

(C) The i-call Research Centre, Switzerland

All rights reserved. No part of this publication may be reproduced, stored in a retrieval system, or transmitted in any form or by any means, mechanical, photocopying, recording or otherwise, without prior written permission of the publisher.

Permission to use this content must be obtained from the copyright owner. 


\section{INSTITUTIONALIZATION OF CREATIVITY IN TRADITIONAL SOCIETIES AND IN INTERNATIONAL TRADE LAW}

1 INTRODUCTION................................................................................. 4

2 CREATIVITY IN TRADITIONAL AND MODERN SOCIETIES .... 6

2.1 THE SYSTEM OF ART AS THE HOST OF CREATIVITY UNDER CONDITIONS OF MODERNITY ......................................................................... 7

2.2 CREATIVITY AND SPIRITUALITY IN TRADITIONAL SOCIETIES ............... 8

2.3 TRADITIONAL CREATIVITY AND GLOBALIZATION ............................. 10

3 HOW IS INDIGENOUS CREATIVITY INSTITUTIONALIZED IN INTERNATIONAL TRADE LAW? ................................................ 12

3.1 THE TRIPS AGREEMENT's BERNE PLUS APPROACH TO CREATIVITY 12 3.2 TRIPS PROVISIONS WITH POTENTIAL RELEVANCE FOR TCE AND TK 14

3.3 THE WIPO AGENDA ON PROTECTING INDIGENOUS CREATIVITY ........ 15

4 ADJUSTING WTO LAW TO SECURING A MORE ACTIVE PART FOR INDIGENOUS CREATIVITY...................................................... 17

4.1 TRIPS NEGOTIATIONS ON INDIGENOUS CULTURAL KNOWLEDGE ...... 17

4.2 A NEW WTO AVENUE TO BE EXPLORED....................................... 19

5 SELF-DETERMINATION OF INDIGENOUS PEOPLES AND INTERNATIONAL TRADE IN TCE .................................................... 22

5.1 THE UN DECLARATION ON THE RIGHTS OF INDIGENOUS PEOPLES AND CULTURAL SELF-DETERMINATION ................................................. 22

5.2 WHO DECIDES WHICH INDIGENOUS HERITAGE CAN BE TRADED? ....... 24

5.3 A PROCEDURAL APPROACH TO INTERFACING GLOBAL LAW AND LOCAL

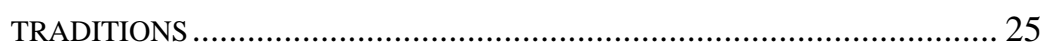




\section{INTRODUCTION}

Creativity is the humus of a prosperous and species-rich cultural environment. Intellectual property rights (IPRs) ${ }^{1}$ are pivotal in fostering creativity since they allow creators to refinance their investments in labour and capital. However, the interrelations between creativity and IPRs have been strongly criticized in the past few years by two groups of legal scholars approaching the topic from two distinct perspectives.

The first group of critics fear that the combined effects of raised standards of IP protection ${ }^{2}$ and technological development endanger a vibrant public domain, which is a prerequisite for creativity in the Internet age. With a focus on copyright law, this so-called public domain movement questions whether the existing IP model appropriately reflects the constitutional balance between the private interests of authors and the public interest in enjoying broad access to their productions. ${ }^{3}$ These critics doubt whether, under the conditions of a digital networked environment, the existing system of IP protection provides the best incentives to promote creativity. Arguably, this balance, constructed in a pre-Internet area of lawmaking, ${ }^{4}$ has been disrupted since digitization and the Internet inflated the value of copyright law ${ }^{5}$ and increased its domain. ${ }^{6}$

1 Intellectual Property is generally divided into two categories: industrial property (including patents, trademarks, industrial designs and geographical indications) and copyright (including literary and artistic works).

2 Over the past 20 years, developed countries have successfully institutionalized strong protection of IPRs at the international level, above all within the framework of the World Intellectual Property Organization (WIPO) and the Agreement on Trade-related aspects of Intellectual Property Rights (TRIPS) of the World Trade Organization (WTO). Since the national treatment obligations enshrined in these instruments automatically secure implementation at national level in all Member States the high international IP standard is now binding for more than 150 states.

3 The positive effects of temporary monopoly rights granted to authors by copyright are paralleled by repercussions for some groups of the general public, who are excluded from gaining access to protected works. See e.g. Julie E. Cohen 'Copyright, Commodification, and Culture: Locating the Public Domain', in L. Guibault and P. B. Hugenhotz (eds), The Future of the Public Domain, The Hague: Kluwer Law International, 2006, pp. 121-166 [hereinafter Cohen, 'Copyright, Commodification, and Culture']; Julie E. Cohen, 'Creativity and Culture in Copyright Theory' (2007) U.C. Davis Law Review, 40, pp. 1151-1205; Jane Ginsburg, "'Une Chose Publique"? The Author's Domain and the Public Domain in Early British, French and US Copyright Law', Columbia Law School, Columbia Public Law Research Paper No. 06-120 (2006), available at http://ssrn.com/abstract=928648; Mark Rose, 'Nine-tenths of the Law: The English Copyright Debates and the Rhetoric of the Public Domain' (2003) Law and Contemporary Problems, 66, pp. 75-87; Pamela Samuelson 'Mapping the Digital Public Domain: Threats and Opportunities' (2003) Law and Contemporary Problems, 66, pp. 147-171; Ruth Towse, 'Copyright and Creativity: An Application of Cultural Economics' (2006) Review of Economic Research on Copyright Issues, 3, pp. 83-91; Hannu Wager, 'Copyright and the Promotion of Cultural Diversity', in Hildegard Schneider and Peter Van den Bossche (eds), Protection of Cultural Diversity from an International and European Perspective, Antwerp: Intersentia, 2008, pp. 193-218.

4 According to Cohen, 'Copyright, Commodification, and Culture', supra note 3, at p. 148, copyright's implicit model of creativity 'remains firmly ensconced in the nineteenth century'.

5 Julie E. Cohen, 'Pervasively Distributed Copyright Enforcement' (2006) Georgetown Law Journal, 95, 1-48.

6 Lawrence Lessig, Code Version 2.0, New York: Basic Books, 2006, p. 193; Lawrence Lessig, '(Re)creativity: How Creativity Lives', in Helle Porsdam (ed.), Copyright and Other Fairy Tales: Hans Christian Andersen and the Commodification of Creativity, Cheltenham, UK: Edward Elgar, 2006, pp. 15-22, at p. 19; Neil W. Netanel, 
A second group of critics has been questioning the relationship of creativity and IPRs from a postcolonialist perspective. This group has been accusing modern IP law of having a colonising effect on indigenous creativity. Arguably, the modern legal narrative of IP is imposed on indigenous forms of social organization and cultural practice. Moreover, IP law reconstructs traditional knowledge (TK) and traditional cultural expressions/folklore (TCE $)^{7}$ in terms of commodities and exclusive rights, whereas indigenous peoples conceive of their cultural knowledge in terms of shared responsibility and find the commodification of sacred ritual objects and practices deeply offensive. ${ }^{8}$ Ultimately, they argue that numerous traditional modes of creative expression remain outside the scope of IP protection, which is due to the inherent centrality of authorship, originality and mercantilism in the modern IP model. ${ }^{9}$

Julie Cohen has rightly emphasized that the postcolonialist critique, identifying lacunas in the protection of indigenous creativity, and the critique of an overbroad copyright protection, as proposed by the public domain movement, converge where "both approaches seek to complicate copyright, replacing its foundational private/public dichotomy with a more fertile mix of rights and privileges". ${ }^{10}$

'Why has Copyright Expanded? Analysis and Critique', in Fiona Macmillan (ed.), New Directions in Copyright Law, vol. VII, Cheltenham, UK: Edward Elgar, 2007, pp. 3-34; see also, Mira Burri-Nenova; Christoph Beat Graber and Thomas Steiner, 'The Protection and Promotion of Cultural Diversity in a Digital Networked Environment: Mapping Possible Advances to Coherence', (forthcoming), at para. E.II.2.

7 In the international context, the cultural dimension of traditional knowledge was originally discussed under the heading of "folklore". Since the term "folklore" has been criticized as having connotations of creations of lower or superseded civilizations, the terms "traditional cultural expressions" and "expressions of folklore" have more recently been used as synonyms in the relevant international fora, instead of the term "folklore". See Michael Blakeney, 'Hans Christian Andersen and the Protection of Traditional Cultural Expressions', in Helle Porsdam (ed.), Copyright and Other Fairy Tales: Hans Christian Andersen and the Commodification of Creativity, Cheltenham, UK: Edward Elgar, 2006, pp. 108-128, at pp. 109-111; Christoph Beat Graber and Martin Girsberger 'Traditional Knowledge at the International Level: Current Approaches and Proposals for a Bigger Picture that Include Cultural Diversity', in Hansjörg Seiler and Jörg Schmid (eds), Recht des Ländlichen Raums. Festgabe der Rechtswissenschaftlichen Fakultät der Universität Luzern für Paul Richli zum 60. Geburtstag, Zurich: Schulthess, 2006, pp. 243-282, at pp. 246-247.

8 Erica-Irene Daes, 'Discrimination Against Indigenous Peoples: Study on the Protection of the Cultural and Intellectual Property of Indigenous Peoples', (UN Doc. E/CN.4/Sub.2/1993/28, 28 July 1993), at para. 22; Antony Taubman, 'Saving the Village: Conserving Jurisprudential Diversity in the International Protection of Traditional Knowledge', in Keith E. Maskus and Jerome H. Reichman (eds), International Public Goods and Transfer of Technology Under a Globalized Intellectual Property Regime, Cambridge: Cambridge University Press, 2005, pp. 521-564, at p. 558; for the Aborigines in Australia see Christoph Beat Graber, 'Aboriginal Self-Determination v Propertisation of Traditional Culture and the case of Sacred Wanjina Sites' (2009) Australian Indigenous Law Review, 13 (2), pp. 18-34, at p. 18.

9 See Christoph Beat Graber, 'Using Human Rights to Tackle Fragmentation in the Field of Traditional Cultural Expressions: An Institutional Approach', in Christoph Beat Graber and Mira Burri-Nenova (eds), Intellectual Property and Traditional Cultural Expressions in a Digital Environment, Cheltenham, UK: Edward Elgar, 2008 pp. 96-120, at pp. 97-99.

10 Cohen, 'Copyright, Commodification, and Culture', supra note 3, at p. 165. WIPO itself admits that certain amendments to the existing IP architecture and a search for new forms of protection are necessary for: (i) the preservation and safeguarding of intangible cultural heritage; (ii) the promotion of cultural diversity; and (iii) the promotion of creativity and innovation, including tradition-based forms. WIPO, Intergovernmental Committee on Intellectual Property and Genetic Resources, Traditional Knowledge and Folklore, 'Consolidated Analysis of the Legal Protection of Traditional Cultural Expressions', (WIPO Doc. WIPO/GRTKF/IC/5/3, 2003), Annex, at para. 8. In September 2007, the General Assembly of WIPO adopted the WIPO Development Agenda, which equally rejects a purely IP-centric view. See WIPO Doc. A/43/16, 2007, at Annex A. 
However, the two views diverge where the public domain movement perceives a stronger protection of indigenous people's IPRs as an incursion into the public domain or a limitation of freedom of expression. ${ }^{11}$

The postcolonialist critique, which shall be the focus of this chapter, seconded indigenous peoples who were for a long time hostile to any commodification of cultural expressions. ${ }^{12}$ In their academic writings, these critics made an important contribution to assembling an inventory of unresolved legal and policy questions in the area of indigenous intellectual and cultural property and heritage. This literature was however mainly defensive, most often accusatory and sometimes even denunciatory. Only recently has a second wave of scholarship started to look past accusations and ask how some communal cultural resources could receive positive protection under IP law and how international law could contribute to assuring a more active role of indigenous peoples in international trade. ${ }^{13}$ In line with this new orientation of scholarship on indigenous cultural heritage, this chapter is intended to contribute to analysing the issue of traditional creativity and international trade law. Since this is a very big new and complex topic, which is the subject of a major research project to be realized over the next couple of years, ${ }^{14}$ this chapter will limit its scope to setting the scene and to identifying some basic issues. It will first briefly discuss the concept of artistic creativity both in modern and in traditional societies. It will then address the phenomenon that the effects of globalization may change indigenous peoples' attitudes towards trade in their cultural heritage. However, whereas some indigenous peoples will welcome the idea that trade in certain expressions of their cultural heritage may contribute to economic development, they will insist on keeping sacred and communally important heritage off the market. Second, the chapter will analyse how indigenous creativity is manifested in current international trade law. Third, we will discuss strategies for adjusting WTO rules in order to respond better to the desire of indigenous peoples to participate more actively in international trade with certain TCE. Finally, the chapter will explore possible implications of the new UN Declaration on the Rights of Indigenous Peoples on trade in indigenous cultural heritage.

\section{CREATIVITY IN TRADITIONAL AND MODERN SOCIETIES}

The way creativity is socially institutionalized differs considerably between modern and traditional societies. To obtain a deeper understanding of this difference we suggest referring to insights gained from Niklas Luhmann's sociological systems theory.

11 See Susy Frankel, 'Trademarks and Traditional Knowledge and Cultural Intellectual Property', in Graeme B. Dinwoodie and Mark D. Janis (eds), Trademark Law and Theory. A Handbook of Contemporary Research, Cheltenham, UK: Edward Elgar, 2008, pp. 433-463, at pp. 459-462, and Wager, supra note 3, at p. 15.

12 See Blakeney, supra note 7, at pp. 112-113.

13 See the various contributions in Christoph Beat Graber and Mira Burri-Nenova (eds), supra note 9, especially those of Miriam Sahlfeld and Christoph Antons.

14 For more information see www.i-call.ch/research projects. 


\subsection{THE SYSTEM OF ART AS THE HOST OF CREATIVITY UNDER CONDITIONS OF MODERNITY}

From a systems theory perspective, the concepts of art or creativity are functionally distinct in modern and traditional societies. Modern society is defined as a system of functionally differentiated autonomous subsystems of communication, including the systems of law, politics, economics, science, religion and art. ${ }^{15}$ Modern society is functionally differentiated because every one of these systems fulfils one specific function exclusively and for the whole society. That is, in modern society, art is conceived of as an autonomous system of communication. ${ }^{16}$ Artistic creation is autonomous in the sense that it does not follow any rules or fulfil any function other than its own..$^{17}$ The artist is conceived of as a communicative artefact of society. ${ }^{18} \mathrm{He}^{19}$ is autonomous in the sense that in his creative work he operates the code of the art system. Consequently, his work is not determined by distinctions which are specific for other communicative systems including politics, the economy or religion.

Since the economy is an autonomous functional system as well, art and the economy are two distinct systems, which both operate their specific code in a process of self-organization. This theoretical setting requires an explanation of the interplay of artistic and economic decisions in a process leading to the creation of an artwork. According to sociological systems theory, the fact that the production of an artefact depends on investments of money or that the final product is destined to be sold on the market does not prevent a creative expression from being an expression of art. In order to understand this important specification, a distinction between the code and the programmes of a system is necessary. Whereas the code determines the unity of the system, programmes are structures that define the conditions of possibility of the

15 Each of these systems may be understood as a kind of language game, and the specific "language" spoken in a system may help to distinguish one system from another.

16 Niklas Luhmann, Die Kunst der Gesellschaft, Frankfurt: Suhrkamp, 1995.

17 The function of art as an autonomous system is to undermine the formalizing tendencies of modern societies and to uncover contingency in the "world making" of formalized social systems and thus to increase communicative chances in society. See Christoph Beat Graber, 'Can Modern Law Safeguard Archaic Cultural Expressions? Observations From a Legal Sociology Perspective', in Christoph Antons (ed.), Traditional Knowledge, Traditional Cultural Expressions and Intellectual Property Law in the Asia-Pacific Region, The Hague: Kluwer Law International, 2009, pp. 159-176, at pp. 165-167, with references to the work of Niklas Luhmann, supra note 16.

18 It is true that the autonomous artist is an invention of modern society. According to Martha Woodmansee, 'The Genius and the Copyright: Economic and Legal Conditions of the Emergence of the "Author"' (1984) Eighteenth-Century Studies, 17: (4), pp. 425-448, at p. 426, the "'author' in its modern sense (...) is the product of the rise in the eighteenth century" of a new group of writers, painters and composers etc. who sought to earn their livelihood from the sale of their art on the market. This explains the artists' pressing need to have legally recognized the ownership of their creative labour in the form of copyright. At the end of the $18^{\text {th }}$ century, when art became autonomous, changes in the production of creative works came together with the rise of a new public. Admiring art is no longer a "prerogative" of a small aristocratic oligarchy but becomes an important means of self-identification of the new middle classes. Christoph Beat Graber, Zwischen Geist und Geld. Interferenzen von Kunst und Wirtschaft aus rechtlicher Sicht, Baden-Baden: Nomos, 1994, at pp. 44-46. However, in contrast to a romantic understanding, the artist is not a god-like genius but rather a communicative artefact. The view of the artist as an individual subject has been deconstructed by French structuralist and post-structuralist philosophers including Michel Foucault and Roland Barthes. For a more detailed discussion see Graber, Zwischen Geist und Geld, at pp. 94-101.

19 Where masculine forms are used in this text, statements apply equally to women. 
code's operation..$^{20}$ Accordingly, the economic modalities of the production or sale of a work of art are defined by the programmes of the art system and do not affect the code's autonomy. ${ }^{21}$

\subsection{CREATIVITY AND SPIRITUALITY IN TRADITIONAL SOCIETIES}

This understanding of aesthetic expressions and of the function of art under conditions of modernity differs considerably from the function that creativity fulfils in a traditional society. Whereas the autonomy of art in modern society finds its expression in the autonomous operation of the artistic code, in a traditional society there are no functionally differentiated systems and religious communication is allpervasive. That is, religious and spiritual purposes also determine creative expressions including dances, songs, stories, paintings or sculpture. TCE and TK are per definition intellectual expressions that have been created within a traditional cultural context. ${ }^{22}$ What the typical features of a traditional culture are can be explained using the example of Aboriginal culture in Australia. For Aborigines in Australia the centre of their spirituality is land. Land is sacred and everything, including creative expression, is related to land. Aborigines believe that their spiritual ancestors came out from underneath the ground to create everything, including the sky, lightening, the rain, waterholes, trees, animals and human beings. ${ }^{23}$ Creative expressions are very important for Aboriginal spirituality, since they commemorate a relationship between the land, the spiritual ancestors and the people. ${ }^{24}$

Emile Durkheim, in the early $20^{\text {th }}$ century, was one of the first anthropologists to describe Australian Aboriginal culture as totemic culture. ${ }^{25} \mathrm{~A}$ totem is generally defined as a natural or supernatural being that spiritually represents a group of related people such as a clan. For Durkheim, the totem is something like the name of a clan. ${ }^{26}$ Within the totemic cosmos of Aboriginal culture, creative artefacts such as carved wood, engraved ornaments and paintings on human bodies have a double function as emblems and as religious symbols. ${ }^{27}$ In their emblematic function he perceived totemic artefacts as a kind of label for a clan, the function of which can be

20 On code and programmes of art, see Luhmann, supra note 16, at pp. 301-340.

21 For an analysis of the interplay between art and the economy from a systems theory perspective, see Christoph Beat Graber and Gunther Teubner, 'Art and Money: Constitutional Rights in the Private Sphere' (1998) Oxford Journal of Legal Studies, 18, pp. 61-73, at p. 71.

22 The word "tradition" refers to the way the knowledge has been passed from generation to generation and the customary rules limiting its use.

23 See e.g. the testimonial of Paddy Neowarra, an Aboriginal elder from the Kimberley region, as quoted in Sylvia Kleinert and Margo Neale (eds), The Oxford Companion to Aboriginal Art and Culture, Oxford: Oxford University Press, 2000, at p. 123.

24 Howard Morphy, Aboriginal Art, London: Phaidon, 1998, at p. 5.

25 Emile Durkheim's renowned book Les Formes Elémentaires de la Vie Religieuse: Le Système Totémique en Australie (The Elementary Forms of Religious Life, [K. Fields trans.]), New York: Free Press, 1995, was first published in 1912.

26 Ibid, at p. 111.

$27 \quad$ Ibid, at pp. 111-117. 
compared with the heraldic coat of arms used in western societies. ${ }^{28}$ As such, it is a proof of the identity of the clan, and each person belonging to the clan is allowed to wear the totem. In its religious function the totemic artefact is used in ceremonies and is part of the liturgy. Things are considered to belong to the sacred or to the profane by reference to the totem..$^{29}$ Contemporary anthropologists too have been stressing the religious function of Aboriginal cultural expressions. According to Ronald Berndt and Catherine Berndt, TCE play a central role in the spiritual life and religious ceremonies of Aborigines ${ }^{30}$ since they stand for ancestral beings, as they "symbolize them or evoke them". ${ }^{31}$

The functional differences of creative expression between traditional and modern societies are mirrored by differences in the social identity and the rights of the artist. In a traditional context, the artist is not seen as an autonomous individual (as in modern art) but as a "re-activator" of the spiritual world. ${ }^{32}$ For Berndt and Berndt "[v]irtually everything he painted or carved or constructed was an act of creation, revivifying the spiritual, transforming it into a tangible, visible focus of ritual behaviour." 33 The rights of the traditional artist are not to be understood in terms of property (as in modern IP law) but in terms of custodianship of indigenous heritage. The indigenous creator's rights to make or perform the artworks are inherited authority and often imply "rights in the land itself". ${ }^{34}$ These vary according to the relationship between the artist and the ancestral beings, and depend on his or her relationship to the land and the "knowledge [of the lands'] spiritual and mythological significance". ${ }^{35}$ The authority to become a custodian of the clan's cultural heritage is received from the clan through initiation and in a special relationship of trust. ${ }^{36}$ The knowledge necessary to create artwork is gained through close collaboration with elder artists and practised to preserve the cultural heritage of the clan. Customary law provides for strict rules regarding technique and content of the artwork and a clan may perceive mistakes as offensive. ${ }^{37}$ The case of Milpurruru $\mathcal{E}$ Ors $v$ Indofurn Pty Ltd \& Ors may illustrate this. Here, the Aboriginal artist Banduk

28 See Elizabeth Burns Coleman, 'Aboriginal Art and Identity: Crossing the Border of Law's Imagination', (2004), Journal of Political Philosophy, 12 (1), pp. 20-40; and Elizabeth Burns Coleman, Aboriginal Art, Identity and Appropriation, Aldershot: Ashgate, 2005, at p. 73.

29 Durkheim, supra note 25, at p. 118.

30 Ronald M. Berndt and Catherine H. Berndt, The World of the First Australians - Aboriginal Traditional Life: Past and Present, Canberra: Aboriginal Studies Press, 1996, at p. 429.

31 Ronald M. Berndt and Catherine H. Berndt, Aboriginal Australian Art, Sydney: Methuen, 1982, at p. 24.

32 Indigenous people in the Kimberley region of Western Australia believe that the famous Wanjina paintings were put on the rocks by the spiritual ancestors themselves. See the affidavit of Paddy Neowarra, an Aboriginal elder, in Neowarra v Western Australia (2003) FCA 1402, at para. 277. Over the centuries, Aboriginal artists have been repainting the Wanjina images whenever the paintings needed it. In doing this they have been following their customary laws. See Graber, supra note 8, at p. 20 and Blakeney, supra note 7 , at p. 120.

33 Berndt and Berndt, supra note 31, at p. 24.

34 Morphy, supra note 24, at p. 107.

35 Morphy, supra note 24, at $\mathrm{p} 108$.

36 Christoph Antons, 'Folklore Protection in Australia: Who is Expert in Aboriginal Tradition?', in Elke KurzMilcke and Gerd Gigerenzer (eds), Experts in Science and Society, New York: Kluwer, 2004, pp. 85-103, at p. 91, referring to Justice von Doussa of the Federal Court of Australia in the case of John Bulun Bulun \& Anor $v$ R E T Textiles Pty Ltd (1998) FCA 1082. See also Michael F. Brown, Who Owns Native Culture?, Cambridge, MA: Harvard University Press, 2003, at p. 46.

37 For examples see Blakeney, supra note 7, at pp. 120-121. 
Marika explained in an affidavit that if the reproduction of one of her traditional paintings on a carpet, by a Vietnamese company, had become known in her community, her clan could have expelled her or ordered her to stop participating in ceremonies or to stop producing any works of art. ${ }^{38}$ The Court noted the possibility of spearing as a further sanction in serious cases. ${ }^{39}$

What has been said above applies to TCE with a religious motive. ${ }^{40}$ Whereas a modern artist is autonomous, a creator of traditional cultural expression is limited in his freedom by the customary laws of his clan. However, as Justice van Doussa explained in Milpurruru $v$ Indofurn

The extent to which Aboriginal law and culture imposes limitations on the reproduction of Aboriginal artwork will vary according to the clans concerned and the significance of the imagery and dreaming which is reflected in the particular artwork. Where the artwork concerns a public story or ceremony there may be few restrictions on reproduction. This is plain from the quantity and variety of artwork presently produced by Aborigines for the commercial market. ${ }^{41}$

Hence, a distinction must be drawn between artefacts with a spiritual significance for the clan and artistic creations that the clan has authorized for commercial sale to museums, art collectors, tourists or other consumers. What is more, the ways in which indigenous peoples make use of their tangible or intangible creative expressions may change depending on the influences of globalization.

\subsection{TRADITIONAL CREATIVITY AND GLOBALIZATION}

As a result of modern mass communication and the Internet, indigenous communities, including Aborigines living in remote areas of Australia, today are more heavily exposed to the global economy. Consequently, it will be difficult for these communities to continue their traditional form of social practice. However, it would be wrong to see modernity or the Internet as simply a threat to local identities. On the contrary, since the Internet may help indigenous communities to overcome isolation, it has been called "an ideal medium for aboriginal communication". ${ }^{42}$ Moreover, the Internet may offer new opportunities to communities which want to take advantage of economic globalization and gradually move towards more modern forms of social organization. ${ }^{43}$ In their incremental shift from tradition to modernity,

$38 \quad$ Milpurruru E Ors v Indofurn Pty Ltd \& Ors (1994) 130 ALR 659, at para. 16.

$39 \quad$ Ibid, at para. 13. On spearing see infra, note 127.

40 On the distinction between traditional and urban artists see Gray, Stephen (1996), 'Black Enough? Urban and Non-Traditional Aboriginal Art and Proposed Legislative Protection for Aboriginal Art' Culture and Policy, 7 (3), pp. 29-44.

$41 \quad$ Milpurruru $\mathcal{E}$ Ors $v$ Indofurn Pty Ltd $\mathcal{E}$ Ors, supra note 38, at para. 18.

42 Rosemary J. Coombe, 'Preserving Cultural Diversity Through the Preservation of Biological Diversity: Indigenous Peoples, Local Communities, and the Role of Digital Technologies', in Fiona Miller et al. (eds), The Gender of Genetic Futures, NNEWH Working Paper Series (2000), pp. 132-160, at p. 148; see also Mira Burri-Nenova, 'The Long Tail of the Rainbow Serpent: New Technologies and the Protection and Promotion of Traditional Cultural Expressions', in Christoph Beat Graber and Mira Burri-Nenova (eds), supra note 9, pp. 205-236, at p. 229.

43 For comprehensive analyses see Burri-Nenova, supra note 42, Miriam Sahlfeld, 'Commercialising Cultural Heritage? Criteria for a Balanced Instrumentalization of Traditional Cultural Expressions for Development in a Globalized Digital Environment', in Christoph Beat Graber and Mira Burri-Nenova (eds), supra note 9, 
they may however want to open up only certain aspects of their lifeworld (Husserl), while sticking to their traditions with regard to their spirituality and religious beliefs.

Moreover, for some communities, including Canada's First Nations and American Indians in the United States whose culture was destroyed a long time ago, the Internet may offer new opportunities to cheaply communicate with one another and with other indigenous peoples across national borders. ${ }^{44} \mathrm{New}$ means of communication may thus contribute to revitalizing indigenous peoples' values ${ }^{45}$ and to forming international coalitions in political matters. Such groups may equally use signs and symbols with a special significance for the community to revive forgotten traditions or to fortify group identity in the changed environment. ${ }^{46}$

The differences in the social institutionalization of creativity in traditional and modern societies outlined above are responsible for many collisions between local traditions and global IP law. On the one hand, indigenous peoples will want to keep their sacred TCE secret and to prevent its unauthorized disclosure and subsequent use. ${ }^{47}$ Thus, in accordance with their traditions, they will insist that sacred and secret artefacts must be kept off the art market. On the other hand, certain artwork will be produced for commercial sale to secure an income for the individual artist or the community. ${ }^{48}$ Hence, a difficult question is: who determines which TCE is sacred and must not be disclosed or traded and which artwork is meant for commercial sale. Is this question to be resolved under the customary rules of indigenous peoples or under modern law? We will come back to these questions in sections 5.2. and 5.3. below.

Where indigenous artists, with the consent of their community, decide to trade their TCE, they may wish to harness existing mechanisms of IP protection to prevent third parties from misappropriating, counterfeiting or otherwise inappropriately using it. However, the existing systems of IP protection were not originally drafted to meet the interests of indigenous peoples and thus modern IP law is not sufficiently responsive to indigenous concerns. ${ }^{49}$ Modern IPRs have numerous flaws in this regard, a few of which are listed here: first, patent or trademark protection will often

pp. 256-286, and, pointing to differences in the reception of modernity between indigenous cultures in Australia and Southeast Asia, Christoph Antons, 'Traditional Cultural Expressions and their Significance for Development in a Digital Environment: Examples from Australia and Southeast Asia', in Christoph Beat Graber and Mira Burri-Nenova (eds), supra note 9, pp. 287-301.

44 Coombe, supra note 42, at p. 147.

45 Christoph Beat Graber and Mira Burri-Nenova, 'Preface', in Christoph Beat Graber and Mira Burri-Nenova (eds), supra note 9 , pp. xi-xiii, at p. xiii.

$46 \quad$ Frankel, supra note 11, at p. 438.

47 For suggestions to use existing concepts of trade secrets and trademark law to protect indigenous sacred works and their inherent limitations see Megan Carpenter, 'Intellectual Property Law and Indigenous Peoples: Adapting Copyright Law to the Needs of a Global Community' (2004) Yale Human Rights and Development Law Journal, 7, pp. 51-78, at pp. 74-76.

48 See Taubman, supra note 8 , at p. 534.

49 TK and TCE are not simply information (i.e., not artistic information in a modern sense) but information with an inherent normative and social component. This raises the problem that as information TK and TCE "can be easily communicated beyond [their] original context", while the norms etc. that define its specific value for a local community would ban its disclosure to unauthorized persons. Taubman, supra note 8 , at p. 524. 
presuppose registration. ${ }^{50}$ This will be a problem for indigenous peoples not having the necessary resources. ${ }^{51}$ Moreover, for preliterate indigenous cultures it will often be inappropriate to register oral TK or TCE since this would contradict tradition, i.e. the process in which this has passed from generation to generation..$^{52}$ Second, with regard to copyright law, fixation requirements will be an obstacle to TCE protection. ${ }^{53}$ Third, even where no formal requirements of protection have to be met, existing IP law falls short of providing the kind of protection for TK and TCE that indigenous peoples seek. For example, systems of unregistered trademark protection often require that a sign is used in trade. This makes such systems unattractive for those signs and symbols which indigenous communities will want to keep out of a trade context. ${ }^{54}$ Similarly, copyright law is unable to protect secret and sacred or very old TCE effectively due to concepts of individual ownership and limited terms of protection. In the next section we will examine more closely the shortcomings of the Agreement on Trade-related Aspects of Intellectual Property Rights (TRIPS Agreement) with respect to effectively protecting indigenous knowledge from unauthorized use.

\section{HOW IS INDIGENOUS CREATIVITY INSTITUTIONALIZED IN INTERNATIONAL TRADE LAW?}

\subsection{THE TRIPS AGREEMENT'S BERNE PLUS APPROACH TO CREATIVITY}

In international trade law, the protection of creativity is most prominently institutionalized in the TRIPS Agreement. The TRIPS Agreement, however, does not provide for a definition of creativity but refers to the Berne Convention. This crossreference to the Berne Convention is made because the TRIPS Agreement is guided by a "Berne Plus" approach as far as copyright protection is concerned. According to the Berne Plus approach, existing standards of protection shall be confirmed and, in specific areas, be supplemented with additional rights. A supplementation of the Berne Convention is provided in Article 10 TRIPS with regard to compilations and computer programs. ${ }^{55}$ Article 10.2 TRIPS, which states that compilations of data must

50 While registration of patents is a general requirement, the trademark systems of many states also provide protection for unregistered signs. See Frankel, supra note 11, at p. 442.

$51 \quad$ Ibid, at pp. 441 and 445.

52 For the case of traditional medicine in Zimbabwe see Rosemary J. Coombe, 'Protecting Cultural Industries to Promote Cultural Diversity: Dilemmas for International Policy-making Posed by the Recognition of Traditional Knowledge', in Keith E. Maskus and Jerome H. Reichman, supra note 8, pp. 599-614, at p. 601.

53 Fixation requirements exist in certain common law countries although, according to Article 2.2 Berne Convention, national laws need not provide that fixation is a general condition for protection. See WIPO, 'Consolidated Analysis of the Legal Protection of Traditional Cultural Expressions/Expressions of Folklore', Background Paper No 1, Geneva: WIPO, 2003, at pp. 41-42.

54 Frankel, supra note 11, at p. 445.

55 Mandating Members to protect original compilations of data or other material together with the protection of computer programs was considered necessary in a special provision of the TRIPS, since the coverage of these works had "remained open to debate" under the Berne Convention. Sam Ricketson, and Jane C. Ginsburg, International Copyright and Neighbouring Rights. The Berne Convention and Beyond, vol. I, 2nd edn, Oxford: Oxford University Press, 2006, at para. 8.120. 
be "intellectual creations" in order to be protected, is the only provision of the TRIPS Agreement where "creativity" is explicitly mentioned.$^{56}$ The confirmation of existing standards finds its expression in Article 9 TRIPS, requiring Members to comply with Articles 1 through 21 of the Berne Convention. Hence, Article 9 TRIPS has the effect of incorporating Articles 1 through 21. ${ }^{57}$ The most important consequence of this incorporation is that international copyright standards become subject to the compulsory dispute settlement system of WTO law. ${ }^{58}$

The Berne Convention, like most Western copyright legislation, requires that to be protected under copyright a work must possess a minimal degree of creativity. ${ }^{59}$ This minimal creativity requirement is often called the "originality" 60 of the work. Originality allows a work to be distinguished from pre-existing works. TCE has been characterized as the result of a constant and slow process of impersonal incremental changes based on imitation of existing works exercised by members of consecutive generations of an indigenous group or people. ${ }^{61}$ Consequently, originality in TCE is low, since TCE is the result of a long chain of minor incremental changes. Since the TRIPS Agreement does not explicitly mention TK or TCE ${ }^{62}$ it is no surprise that legal scholars have been arguing that the TRIPS Agreement would not apply to issues of TCE. According to Peter Van den Bossche, TCE and TK and other expressions of "low originality" are not covered by the disciplines of the TRIPS Agreement. ${ }^{63}$

Doris Long has rightly emphasized that the fact that the TRIPS Agreement does not explicitly refer to issues of TCE and does not provide for a definition of "originality" nor otherwise specify any creativity requirements for a copyrightable

56 Doris Estelle Long, 'The Impact of Foreign Investment on Indigenous Cultures: An Intellectual Property Perspective' (1998) North Carolina Journal of International Law and Commerce Regulation, 23, pp. 229-280, at p. 257.

$57 \quad$ Article $6^{\text {bis }}$ Berne Convention is explicitly excluded from this incorporation.

58 According to Article 1.1 of the Understanding on Rules and Procedures Governing the Settlement of Disputes (DSU) the rules and procedures of the DSU apply to disputes between WTO Members brought pursuant to the dispute settlement provisions of the 'covered agreements' listed in Appendix 1 of the DSU including, inter alia, the GATT 1994, the GATS and the TRIPS Agreement.

59 Article 2(1) Berne Convention provides a list of works that must be protected by the contracting parties without, however, defining the quality or quantity of creativity that must be inherent in a work in order to require its protection. See Ricketson and Ginsburg, supra note 55, at para. 8.05.

60 For a discussion of the low level of creativity required by US law see Long, supra note 56, at p. 264, n. 146. The Supreme Court held in Feist Publications, Inc v Rural Telephone Service, Co (1991) 499 US 340, at 355 that the copyrightability of an alphabetically organized phone book comprises two elements: "that the work was independently created by the author (as opposed to copied from other works), and that it possesses at least some minimal degree of creativity."

61 Daphne Zografos, 'The Legal Protection of Traditional Cultural Expressions: Is Copyright the Answer?', in Fiona Macmillan (ed.), New Directions in Copyright Law, vol. II, Cheltenham, UK: Edward Elgar, 2006, pp. 181-197, at p. 184; see also Mihály Ficsor, The Law of Copyright and the Internet, Oxford: Oxford University Press, 2002, at para. 10.68, and Cathryn A. Berryman, 'Toward More Universal Protection of Intangible Cultural Property' (1994) Journal of Intellectual Property Law, 1, pp. 293-333, at pp. 310-311 (discussing Kamal Puri's description of Folklore, see Kamal Puri, (1988), 'Copyright Protection of Folklore: A New Zealand Perspective' (2003)Copyright Bulletin, 22, pp. 18-27).

62 Taubman, supra note 8, at 543; Graham Dutfield, 'Protecting Traditional Knowledge: Pathways to the Future', International Centre for Trade and Sustainable Development, Issue Paper No. 16 (2006), at p. 33, available at http://www.iprsonline.org/unctadictsd/docs/Graham\%20final.pdf (accessed January 2009).

63 Peter Van den Bossche, The Law and Policy of the World Trade Organization, 2nd edn, Cambridge: Cambridge University Press, 2008, at p. 747, n. 22. 
work does not automatically preclude TCE from protection. ${ }^{64}$ Taking account of the cross-reference enshrined in Article 9 TRIPS, with regard to this question, a closer investigation into the Berne Convention is necessary. Such an investigation reveals that the protection of TCE (folklore) is not completely absent from the Berne Convention. Rather, the inadequacy of the Berne Convention with regard to folklore was debated during the 1967 Stockholm Revision Conference. On this occasion, India proposed to include folklore in the enumeration of literary and artistic works in Article 2(1). ${ }^{65}$ However, the Indian proposal raised difficult problems including defining folklore, delimiting it from the public domain and coping with situations where no individual author could be identified. Consequently, the conference considered amending Article 15(4) and treating folklore as a special category of anonymous work within the meaning of this article. ${ }^{66}$ The provision as it was adopted in the Stockholm Act reads as follows:

Article 15(4)

(a) In the case of unpublished works where the identity of the author is unknown, but where there is every ground to presume that he is a national of a country of the Union, it shall be a matter for legislation in that country to designate the competent authority which shall represent the author and shall be entitled to protect and enforce his rights in the countries of the Union.

Although the term "folklore" was not explicitly mentioned and the provision applied to all works fulfilling the conditions set out in paragraph (4) of Article 15, according to Ricketson and Ginsburg it was clear to the contracting parties that productions of folklore were "its main field of application". ${ }^{67}$ However, as most works of folklore have already been published, Article 15(4) Berne Convention fails to provide effective protection for this large category.

What is more, existing TCE will not be protected because it exceeds the time limits for protection provided by national copyright regimes. New TCE however, which is based on pre-existing TCE, ${ }^{68}$ may become protected since different levels of originality may be required in different jurisdictions and common law countries, in particular, are known not to require a high level of originality. ${ }^{69}$

\subsection{TRIPS PROVISIONS WITH POTENTIAL RELEVANCE FOR TCE AND TK}

Without explicitly referring to indigenous creativity, provisions of the TRIPS Agreement on trade secrets/protection of undisclosed information (Article 39), trademarks (Articles 15 to 21) and geographical indications (Articles 22 to 24) may be

64 Long, supra note 56, at pp. 257 and 272.

65 Ricketson and Ginsburg, supra note 55, at para. 8.118.

66 Ibid.

67 Ibid.

68 Note that Article 2(a) WIPO Performances and Phonograms Treaty (WPPT), adopted in 1995, extends performers rights to recordings of expressions of folklore. Under Article 2(a) WPPT, an audiovisual fixation may be protected as a "phonogram" even if the underlying audiovisual fixation does not qualify as a work. See Ficsor, supra note 61, at paras PP2.04 and PP2.07.

69 Zografos, supra note 61, at p. 184. 
of relevance to indigenous culture. However, all three concepts would squeeze indigenous interests into a system of modern IP law that was not designed with a policy of responding to what indigenous peoples actually seek. With regard to the protection of undisclosed information, fulfilling inter alia the requirement to take steps to keep the information secret (Article 39.2(c)) will be difficult for preliterate communities who often use magic or other mysterious power over imagination for such purposes and have no written records. ${ }^{70}$ In the case of trademarks, according to Article 15.1 TRIPS, signs may be protected if they are "capable of distinguishing the goods and services of one undertaking from those of other undertakings". Consequently, a sign cannot exist independently from a good or a service. Although many TCE may fit the definition of a sign, they will nonetheless not be considered as a trademark, because "the sign is not applied to goods and services or not used to distinguish goods and services in a trade context". ${ }^{71}$ Finally, the concept of geographical indications (GI) is a relative of the trademark that has received much attention in the realm of recent negotiations on TRIPS. ${ }^{72}$ Since many TCE are conceived by their creators in relation to land and other geographical indicators, GI seem at first sight to be an attractive tool for protection. ${ }^{73}$ However, a closer analysis reveals a number of difficulties that arise when this concept is applied to indigenous creativity. To mention just two: first, what is protected under GI is the indication and not the knowledge or cultural expression ${ }^{74}$ and, second, indigenous concepts of communal "ownership" will often make it impossible to find the appropriate rights holder. ${ }^{75}$

\subsection{THE WIPO AGENDA ON PROTECTING INDIGENOUS CREATIVITY}

The above-identified shortcomings of the international IP system with regard to the protection of TK and TCE gave rise in 2000 to the establishment of an Intergovernmental Committee on Intellectual Property and Genetic Resources, Traditional Knowledge and Folklore (IGC) by WIPO's General Assembly. The WIPO IGC took up its work in 2001 and has since met 14 times. So far, it has neither been

70 For an anthropologist's analysis of the use of magic to control the dissemination of information in preliterate societies see Marc C. Suchman, 'Invention and Ritual: Notes on the Interrelation of Magic and Intellectual Property in Preliterate Societies' (1989) Columbia Law Review, 89, pp. 1264-1294, at pp. 12721279. On the inadequacy of Article 39.2 TRIPS Agreement to protect secrets in traditional societies see also Daniel J. Gervais, 'The Internationalization of Intellectual Property: New Challenges from the Very Old and the Very New', (2002) Fordham Intellectual Property Media \& Entertainment Law Journal, 12, pp. 929-990, at p. 968.

71 Frankel, supra note 11, at p. 445.

72 For the state of current negotiations on GI in the TRIPS Council see http://www.wto.org/English/tratop_e/trips_e/gi_e.htm (accessed 2 March 2009).

73 Taubman, supra note 8, at pp. 524 and 560; Michael Blakeney, 'Protection of Traditional Knowledge by Geographical Indications', in Christoph Antons (ed.), Traditional Knowledge, Traditional Cultural Expressions and Intellectual Property Law in the Asia-Pacific Region, The Hague: Kluwer Law International, 2009, pp. 87108.

74 Taubman, supra note 8, at p. 560.

75 See Gervais, supra note 70, at p. 968. For more information on shortcomings of solutions based on geographical indications in the field of indigenous knowledge see Taubman, supra note 8, at p. 528; Frankel, supra note 11, at pp. 452-453. 
able to establish a working definition of the terms TK and TCE nor has it agreed on policy objectives of the protection of TK and TCE. ${ }^{76}$ In 2005, the Secretariat of the WIPO IGC prepared draft provisions for a sui generis protection of TCE, ${ }^{77}$ which have subsequently been the subject of controversial discussion at several meetings of the WIPO IGC. Although the draft has been welcomed by some members it has been severely criticized by others and adoption still seems to be very far away. ${ }^{78}$

The WIPO IGC draft rests on the concept that TCE derive their significance from community recognition rather than from an individual's mark of creativity. ${ }^{79}$ It responds to many of the above-mentioned objections to the use of the existing IP system to protect TCE. First, Article 1 of the Draft provides for a definition of TCE that does not require any reduction to a material form. Protection of TCE automatically exists from the moment of its creation. According to Article 1, TCE can be created either by communities or individuals. Article 3, in defining the scope of protection, distinguishes between: a) TCE of a particular value or significance; b) other TCE; and c) secret TCE. Hence, the WIPO draft distinguishes three layers of protection with TCE that have no particular communal importance at the bottom. For such TCE, government regulation should be limited to requiring that the TCEowning community is identified and to providing the terms under which these TCE shall be used by third parties. ${ }^{80}$ The second layer applies to TCE "of particular cultural or spiritual value or significance". These TCE would receive stronger protection, which would, on top of the protection afforded through layer 1, encompass a right to say no for the indigenous community involved. That is, the reproduction and dissemination of these TCE would be prohibited in the absence of the free, prior and informed consent (FPIC) of the community. To benefit from this enhanced protection, TCE must be registered or notified, as prescribed in Article 7. For TCE that falls within the category of literary and artistic productions, the scope of protection would be based on copyright, whereas for signs, symbols and other marks, the scope of protection would include trademark-type protection. ${ }^{81}$ The third layer provides for the highest level of protection for secret TCE. Such TCE would be protected against disclosure and - if disclosed without authorization - against appropriation and use by third parties (Article 3(c)). Finally, Article 6 provides that protection of TCE should endure for as long as the TCE continue to meet the criteria for protection under Article 1, i.e. for TCE referred to in Article 3(a) as long as they

76 Martin A. Girsberger, 'Legal Protection of Traditional Cultural Expressions: A Policy Perspective', in Christoph Beat Graber and Mira Burri-Nenova (eds), supra note 9, pp. 123-149, at p. 133; Wend B. Wendland, "'It's a Small World (After All)": Some Reflections on Intellectual Property and Traditional Cultural Expressions', in Christoph Beat Graber and Mira Burri-Nenova (eds), supra note 9, pp. 150-181, at p. 159; Graber and Girsberger, supra note 7, at p. 260.

77 The draft provisions are contained unaltered in the Annex of documents WIPO/GRTKF/IC/8/4, 8 April 2005; WIPO/GRTKF/IC/9/4， 9 January 2006; WIPO/GRTKF/IC/10/4， 2 October 2006; WIPO/GRTKF/IC/11/4(c), 26 April 2007; and WIPO/GRTKF/IC/12/4(c), 6 December 2007.

78 The draft was discussed at the Eighth, Ninth, Tenth, Eleventh, Twelfth and Thirteenth Sessions of the Committee. See Wendland, supra note 76, p. 159.

79 According to Article 2, indigenous communities are the principal beneficiaries of protection. Ibid, at p. 171.

80 Ibid, at p. 179. According to Article 3(b), such TCE must not be distorted, mutilated or otherwise modified (i) and third parties must not use false, confusing and misleading indications (ii). According to Article 3(b)(iii), equitable remuneration of and benefit-sharing for the TCE-owning community must be assured.

81 Ibid. 
remain registered, and for TCE referred to in Article 3(c) as long as they remain secret.

The WIPO IGC draft provides for a framework at the level of international law, which must be implemented by national governments and thus leaves enough leeway for fine-tuning according to the specific situations in different jurisdictions. The draft rejects a purely defensive approach to IP protection of TCE. ${ }^{82}$ In accordance with the claims of many indigenous peoples, a defensive strategy is complemented by the positive protection of distinct rights in TCE. ${ }^{83}$ However, the draft does not maximize exclusive rights of indigenous peoples. Rather, the draft is inspired by the idea of balancing exclusive rights of indigenous communities with access rights of the general public for the sake of securing a vibrant creative ecology. According to Wendland, the draft "seeks to recognize that cultural vitality, creativity and diversity stem in large measure from the freedom of authors and performers, including those from within indigenous and local communities, to draw from and be inspired by the cultural expressions of others." ${ }^{84}$ Although the draft seems very promising, it raises two important questions. First, will the registration and notification requirements for enhanced protection of spiritually and communally important TCE not set insurmountable financial or technical stakes for the TCE-holding Aboriginal community? Second, is it sufficient to require "adequate and effective legal and practical measures" of implementation? This is a difficult question because effective protection of TCE, which is often land-tied, would sometimes call for acknowledging rights of indigenous peoples to deny access to sacred sites where artworks are located or ceremonies are performed. This, however, would clearly go beyond the scope of classical measures of IP enforcement.

\section{Adjusting WTO LAW TO SECURING A MORE ACTIVE PART FOR INDIGENOUS CREATIVITY}

\subsection{TRIPS NEGOTIATIONS ON INDIGENOUS CULTURAL KNOWLEDGE}

The shortcomings of the TRIPS Agreement in respect of TK protection, as discussed above, led the WTO Ministerial Conference to adopt, in the realm of the Doha trade negotiation round in November 2001, a Ministerial Declaration that, in paragraph 19, explicitly instructs the TRIPS Council ${ }^{85}$ to examine, inter alia, "the protection of traditional knowledge and folklore". ${ }^{86}$ Whereas the Doha work programme adopted by the General Council on 1 August 2004 made no mention of

82 A defensive approach would be limited to making sure that IP rights do not apply to TCE.

83 According to Taubman, supra note 8, at pp. 534, TCE holders opt for sui generis models of TCE protection rather than for a merely defensive approach based on existing IP law.

84 Wendland, supra note 76, at p. 179.

85 Council for Trade-Related Aspects of Intellectual Property Rights (TRIPS Council) is one of the three sectoral Councils operating under the General Council. It is the body, open to all Members of the WTO, responsible for the administration of the TRIPS Agreement and in particular for monitoring the operation of the Agreement.

86 WTO, 'Doha Ministerial Declaration', (WTO Doc. WT/MIN(01)/DEC/1, 2001). 
the issues of TK and folklore, the Hong Kong Ministerial Conference reaffirmed the mandate of the TRIPS Council in paragraph 44 of its Declaration adopted on 18 December $2005 .{ }^{87}$ On the one hand, both Ministerial Declarations thereby formalized the TRIPS Council's work programme, which had started a few years before the first Declaration in the context of the review of Article 27.3(b) of the TRIPS Agreement. ${ }^{88}$ Article 27.3(b) provides exceptions to the general rule that patents are to be available for any inventions. It relates to the issue of TK in as far as it contains the exception that allows countries to exclude certain types of inventions from patenting, i.e. plants, animals and "essentially" biological processes. On the other hand, the Ministerial Declarations did not limit the examination to the questions relating to TK (and its patentability), but added to the TRIPS Council's mandate the examination of the protection of "folklore" which tends to be examined more through the lens of copyright. Up to now, most statements made in the TRIPS Council have related to TK and relatively little has been said with respect to TCE or folklore. ${ }^{89}$ One of key focuses of the discussion is the relation of the TRIPS Agreement to the Convention on Biological Diversity (CBD). ${ }^{90}$ Since 2003, the work on this point has also been undertaken outside the work programme of the TRIPS Council as part of a consultative process carried out by the Director-General of the WTO. His report of 9 June $2008^{91}$ was fed into the July 2008 ministerial meeting, but there was no outcome to this meeting. However, the Doha Round is continuing and there are no indications that the protection of TK and folklore should be removed as a fixed agenda point of the TRIPS Council's meetings.

The fact that TK and TCE became an issue of WTO law is mainly a result of developing countries entering the fora where international IPRs are being discussed and negotiated. ${ }^{92}$ Their participation has also led to a more or less direct representation of indigenous peoples' interests at an international level, not least since aboriginal communities in several countries have gained political importance. ${ }^{93}$ Bolivia, for example, the first state to be governed by an indigenous president, clearly

87 WTO, 'Hong Kong Ministerial Declaration', (WT/MIN(05)/DEC, 2005). Paragraph 44 reads as follows: “We take note of the work undertaken by the Council for TRIPS pursuant to paragraph 19 of the Doha Ministerial Declaration and agree that this work shall continue on the basis of paragraph 19 of the Doha Ministerial Declaration and the progress made in the Council for TRIPS to date. The General Council shall report on its work in this regard to our next Session."

88 Hannu Wager, 'Biodiversity, Traditional Knowledge and Folklore: Work on Related IP Matters in the WTO' (2008) Intercultural Human Rights Law Review, 3, pp. 215-227, at p. 218.

89 WTO, TRIPS Council Secretariat, 'The Protection of Traditional Knowledge and Folklore: Summary of Issues Raised and Points Made', (WTO Doc. IP/C/W/370/Rev.1, 2006), at p. 2.

90 Girsberger, supra note 76, at p. 134.

91 WTO, General Council Trade Negotiations Committee, Report by the Director-General, 'Issues Related to the Extension of the Protection of Geographical Indications Provided for in Article 23 of the TRIPS Agreement to Products other than Wines and Spirits and those Related to the Relationship Between the TRIPS Agreement and the Convention on Biological Diversity', (WTO Doc. WT/GC/W/591 - TN/C/W/50, 2008).

92 According to Gervais (supra note 70, at p. 941) "[t]he participation of these countries is essential to ensure that intellectual property norms are understood by all and updated in ways that reflect the concerns of all nations at the tables to negotiate."

93 Ibid, at p. 956. 
advocates an indigenous perspective. This has become obvious in the TRIPS Council. ${ }^{94}$

The views on the question whether the WTO would be the right international forum to deal with TK and TCE/folklore are divided in the academic literature. Graham Dutfield, as one of the opponents of such a strategy, states that "[t]he WTO is not an appropriate venue for establishing new norms on positive traditional knowledge protection that would require the insertion of additional text to the TRIPS Agreement and the possible deletion of existing text." ${ }^{95}$ Proponents, however, emphasise that the fallback on the TRIPS Agreement and the WTO might be useful to complement WIPO's work on issues of TK and folklore and "would allow for action to be taken on pressing matters which appear not to be a priority for WIPO". ${ }^{96}$ From the perspective of the dynamics at the negotiation table, the success of the next round of global trade talks might even depend on how the parties deal with traditional knowledge and TCE/folklore, since the support of several developing and other countries will be crucial to moving forward with updating the TRIPS Agreement. ${ }^{97}$

In our view, WIPO is the specialized intergovernmental organization to deal with IP issues and to develop new substantive rules on IP. However, TRIPS (and WTO at large) become relevant for the implications of IP systems on the conditions of competition in international trade since it is the rationale of the TRIPS Agreement to balance the competing private interests of holders of IPRs and the public interest to assure the free flows of goods and services across borders. ${ }^{98}$ Moreover, thanks to the WTO's impressive dispute settlement system, the TRIPS forum seems to be more advantageous for governments seeking international IPR enforcement. Accordingly, with a view to effectively protecting indigenous peoples' creativity, it will be crucial to assure that new rules on TK and TCE developed within the WIPO system are also recognized by the TRIPS/WTO framework. The situation in which TRIPS members can ignore new substantive rules on indigenous creativity that may developed within a WIPO or another treaty should be avoided. Hence, developing an interface between WIPO and TRIPS/WTO with regard to issues of TK and TCE should be an item high on the agenda of both organizations. Issues of cooperation and attribution of responsibilities of WIPO and TRIPS/WTO will thus have to be closely followed and reflected in further research on the subject.

\subsection{A NEW WTO AVENUE TO BE EXPLORED}

94 In this body, Bolivia's representative stated inter alia that Bolivia perceives TK and folklore (or TCE) as being part of one single, holistic cultural tradition, and thereby refuses the pure IP perspective realized in the TRIPS Agreement. See e.g. the WTO, 'Minutes of the Meeting on 17 June 2008 of the TRIPS Council', (WTO Doc. IP/C/M/5, 2008); the representative of Bolivia stated at that meeting that her delegation was in favour of protecting genetic resources, their derivative products and TK, but neither agreed nor believed that this should be done through the patent system. Her delegation believed it was necessary to consider other creative non-patent-based solutions to the collective IP issue.

95 Dutfield, supra note 62, at para. 6.2.

96 Paul Kuruk, 'Bridging the Gap Between Traditional Knowledge and Intellectual Property Rights: Is Reciprocity an Answer?' (2004) Journal of World Intellectual Property, 7 (3), pp. 429-446, at p. 436.

97 Gervais, supra note 70, at p. 954.

98 See Thomas Cottier, 'The Agreement on Trade-Related Aspects of Intellectual Property Rights', in Patrick F. J. Macrory et al. (eds), The World Trade Organization: Legal, Economic and Political Analysis, vol. I, New York: Springer, 2005, pp. 1041-1120, at p. 1054. 
In addition to the TRIPS Agreement, an inquiry into new ways of facilitating trade in indigenous cultural heritage should include the GATT and the GATS. ${ }^{99}$ Considering the high political importance of the new UN Declaration on the Rights of Indigenous Peoples (see section 5 below), we suggest thinking about preferential rules for WTO Members who respect the rights of their indigenous peoples with respect to cultural self-determination and self-governance.

To explore such a strategy, it will be important to look for analogies in existing WTO rules on special and differential (S\&D) treatment for developing countries. Existing rules on S\&D treatment include provisions assuring, for example, longer transitional time periods, flexibility of commitments or technical assistance. The most important rules on S\&D treatment, however, are enshrined in the so-called "Enabling Clause". The Enabling Clause is the name for a decision taken by the GATT Members in 1979 to afford "differential and more favourable treatment" to developing countries, which was incorporated into GATT 1994. ${ }^{100}$ The interpretation of the Enabling Clause was at issue in the report of the WTO Appellate Body (AB) in EC Preferences. ${ }^{101}$ The $\mathrm{AB}$ held that the Enabling Clause did not require Members to treat all developing countries in the same way. However, the $A B$ noted that Members must ensure identical treatment of developing countries that are in similar situations. Consequently, the EC was authorized under the Enabling Clause to offer a preferential tariff scheme to developing countries engaging in special measures to combat the trafficking of drugs. However, the EC was not allowed to limit such a tariff scheme to a closed number of developing countries but was required to open it to all developing countries engaging in similar anti-drug measures. ${ }^{102}$

This ruling of the $A B$ may support our strategy since it allows Members of the WTO to set specific conditions of public policy in their General System of Preferences programmes, such as fulfilment of higher labour or environmental standards,

Under the existing law, Article XX(f) GATT provides an express exception to the general prohibition of export controls for national treasures "possessing artistic, historic, or archaeological importance". Indigenous peoples' artefacts, however, are usually not considered "national" treasures. The GATS does not provide for specific rules on cultural services of indigenous origin.

100 See of, GATT/WTO, 'Differential and More Favourable Treatment, Reciprocity and Fuller Participation of Developing Countries', GATT/WTO Decision (GATT Doc. L/4903, 1979). For more information see: Bernard Hoekman, 'More Favorable Treatment of Developing Countries: Ways Forward', in Richard Newfarmer (ed.), Trade, Doha, and Development: Window into the Issues, Washington, DC: World Bank, 2006, pp. 213-221; Seung W. Chang, 'WTO for Trade and Development Post-Doha' (2007) Journal of International Economic Law, 10 (3), 553-570; Van den Bossche, supra note 63, at pp. 728-731.

101 In EC-Preferences the AB first clarified that the Enabling Clause is an exception to the Most Favoured Nation (MFN) Obligation of Article I GATT. At the origin of this case was a complaint by India against certain aspects of the EC's former generalized tariff preferences for developing countries. India claimed that the Drug Arrangements provided by the EC's General System of Preferences (GSP) discriminated between developing countries and thus was in violation of the MFN obligation of the GATT. The Drug Arrangement at issue consisted of special measures within the EC's GSP, designed to combat drug production and trafficking. This Drug Arrangement of the EC consisted of a preferential tariff scheme in favour of 12 Latin American countries and Pakistan. India claimed that the Drug Arrangement was not justified by the Enabling Clause since the preferential tariff scheme was not extended to all developing countries but limited to a few countries selected by the EC. See WTO, Appellate Body Report, European Communities - Conditions for the Granting of Tariff Preferences to Developing Countries, WT/DS246/AB/R, adopted 20 April 2004.

102 Since the EC's Drug Arrangement was limited to a few countries selected by the EC, the AB came to the conclusion that this GSP was not justified by paragraph 2(a) of the Enabling Clause and thus violated the MFN obligation of the GATT. 
provided that such rules are applied without discrimination. Although existing rules on S\&D treatment are limited to developing countries, it seems promising to use this case law as a benchmark for thinking about preferential rules for indigenous cultural goods (or services) imported from countries that respect the rights of cultural selfdetermination and self-governance of their indigenous peoples.

Unfortunately, the new UNESCO Convention on Cultural Diversity ${ }^{103}$ (CCD) is not of much help in supporting such a strategy since it does not respond sufficiently to the interests of indigenous peoples. Article $16 \mathrm{CCD}$ provides that developed countries shall accord "preferential treatment to artists and other cultural professions and practitioners, as well as cultural goods and services from developing countries". In contrast to most other provisions of the Convention, which are of a non-binding nature, Article 16 is a clear-cut obligation. ${ }^{104}$ However, Article 16 CCD does not recognize the specific interests of indigenous peoples in developing as well as developed countries. ${ }^{105}$ This is because the CCD was designed by its drafters to protect national entertainment industries rather than creative expressions of indigenous peoples. ${ }^{106}$ Indeed, a reference to TCE and indigenous peoples was introduced only at a late stage of the negotiations. ${ }^{107}$ Although the adopted text does mention TCE and indigenous peoples a few times, ${ }^{108}$ the relevant provisions do not address the rights of the indigenous peoples themselves but those of the states whose territory is affected. ${ }^{109}$ Hence, as is typical for instruments of public international law, the centrality of state sovereignty is a guiding principle underpinning the CCD. ${ }^{110}$ As a consequence, all rights and obligations stemming from the CCD are attributed to states. This is particularly disturbing with regard to the relationship between

103 UNESCO, Convention on the Protection and Promotion of the Diversity of Cultural Expressions, adopted at the 33 ${ }^{\text {rd }}$ Session of the General Conference of UNESCO, 20 October 2005, entered into force 18 March 2007.

104 See Christoph Beat Graber, 'Substantive Rights and Obligations Under the UNESCO Convention on Cultural Diversity', in Hildegard Schneider and Peter Van den Bossche (eds), supra note 3, pp. 141-162, at p. 151.

105 It is noteworthy that the ongoing discussions at UNESCO on the implementation of Article 16 CCD, Switzerland - in its response to a questionnaire distributed by the Intergovernmental Committee (established under the CCD) - suggested taking account of TK and TCE. See http://www.unesco.org/culture/culturaldiversity/Suisse (accessed 11 March 2009).

106 See Federico Lenzerini, 'Indigenous Peoples' Cultural Rights and the Controversy Over Commercial Use of their Traditional Knowledge', in Francesco Francioni and Martin Scheinin (eds), Cultural Human Rights, Leiden etc.: Martinus Nijhoff Publishers, 2008, pp. 119-149, at p. 130.

107 See Christoph Beat Graber, 'Traditional Cultural Expressions in a Matrix of Copyright, Cultural Diversity and Human Rights', in Fiona Macmillan (ed.), New Directions in Copyright Law, vol. V, Cheltenham, UK: Edward Elgar, 2007, pp. 45-71, at pp. 54-55.

108 Paragraph 8 of the preamble recognizes, "the importance of traditional knowledge". Furthermore, paragraph 13 of the preamble recognizes that diversity of cultural expressions, including "traditional cultural expressions", is an important factor that allows peoples and individuals to express and to share with others their ideas and values. Finally, paragraph 15 of the preamble, Article 2 (principle 3) and Article 7.1(a) refer to the relevance of the CCD for persons belonging to indigenous peoples.

109 Mira Burri-Nenova, 'Trade Versus Culture in the Digital Environment: An Old Conflict in Need of a New Definition' (2009) Journal of International Economic Law, 12, pp. 17-62, at p. 25; Burri-Nenova, Graber and Steiner, supra note 6, at para. E.II.

110 Rachel Craufurd Smith, 'The UNESCO Convention on the Protection and Promotion of Cultural Expressions: Building a New World Information and Communication Order?' (2007) International Journal of Communication, 1, pp. 24-55, at p. 37. The sovereignty of the State Parties in the cultural field is included in Article 2(2) as one of the eight guiding principles underpinning the Convention. 
indigenous peoples and the governments of the territory where they live and does not respect the rights of indigenous peoples to cultural self-determination and selfgovernance, which are, as we will see in the next section, the fundament of the UN Declaration on the Rights of Indigenous Peoples.

\section{SELF-DETERMINATION OF INDIGENOUS PEOPLES AND INTERNATIONAL TRADE IN TCE}

The adoption of the UN Declaration on the Rights of Indigenous Peoples (DRIP) in 2007111 opened a new chapter in the debates on indigenous issues in international law and policymaking. In our view, the new Declaration should also play a major role when it comes to assessing and adjusting international rules on trade in TCE. Accordingly, when governments consider how to implement the Declaration, they will have to reflect on the implications for obligations under existing trade agreements. The question of how the rights of indigenous self-determination interface with rules on international trade is extremely complex and requires research beyond this chapter. In this section, we first identify the provisions of the new Declaration related to the cultural self-determination and self-governance of indigenous peoples. Second, we will ask how the recognition of indigenous selfdetermination might affect the question of who decides which TCE can be traded and which not. Finally, a procedural solution will be proposed to regulate the interplay between international law and indigenous custom when such questions arise.

\subsection{THE UN DECLARATION ON THE RIGHTS OF INDIGENOUS PEOPLES AND CULTURAL SELF-DETERMINATION}

Indigenous peoples did not benefit from the decolonization wave triggered in 1960 by the UN General Assembly Resolution 1514(XV) on the Granting of Independence to Colonial Countries and Peoples. ${ }^{112}$ This was due to an interpretation of the term "peoples" that was state-centred and did not extend to indigenous peoples living within the boundaries of an established state ${ }^{113}$ - despite their claim to be recognized as full nations with the right to self-determination. Since the Resolution subordinates indigenous peoples to the sovereignty of states, it impeded "the recognition of various political and property rights, including intellectual property rights, of Indigenous Peoples and traditional communities."114

From the postcolonialist critique we learn that the shortcomings of modern law in effectively protecting indigenous heritage against misappropriation are rooted in the fact that indigenous laws and customs are subjugated under Western law rather

111 The Declaration was adopted on 13 September 2007. See UN, General Assembly, 'General Assembly Adopts Declaration on Rights of Indigenous Peoples', Press Release (UN Doc. GA/10612, 13 September 2007).

112 UN General Assembly Resolution 1514 (XV), adopted 14 December 1960.

113 Gudmundur Alfredsson, 'Indigenous Populations, Protection', in Rudolf Bernhardt (ed.), Encyclopaedia of Public International Law, vol. II, Amsterdam: Elsevier, 1995.

114 Blakeney, supra note 7, at p. 116. 
than recognising the Aboriginal peoples' right to self-determination over cultural heritage. Self-determination of peoples, including cultural self-determination, is guaranteed as an international human right in Article 1 of the UN Covenant on Civil and Political Rights (CCPR). ${ }^{115}$ However, it is still not clear whether Article 1 is merely a vague political principle or a genuine right. ${ }^{116}$ Moreover, it is a matter of considerable controversy whether indigenous communities are "peoples" in the sense of Article $1^{117}$ rather than "minorities" in the sense of Article 27 CCPR. ${ }^{118} \mathrm{In}$ light of these uncertainties, ${ }^{119}$ it is important to note that the DRIP specifically endorses both the right of (collective) self-determination (Article 3) and the right of (collective) self-government (Article 5). ${ }^{120}$ Several provisions relating to issues relevant for the protection and preservation of TK, TCE, cultural heritage and important sites can be read as a foldout of the right of self-determination (or selfgovernment) in the field of cultural and spiritual issues. Article 25 of the Declaration provides that "indigenous peoples have the right to maintain and strengthen their distinctive spiritual relationship with their traditionally owned or otherwise occupied and used lands, territories, waters and coastal seas and other resources and to uphold their responsibilities to future generations in this regard". Articles 11 and 12 both refer (using almost identical language) to the rights of indigenous peoples to maintain, protect, develop or have access to sacred sites as part of their right to practice and revitalize their cultural traditions and customs (Article 11) and/or their right to manifest, practise, develop and teach their spiritual and religious traditions, customs and ceremonies (Article 12). With a view to implementing the rights

115 Article 1 CCPR, which is formulated in language identical to that of Article 1 of the UN Covenant on Economic, Social and Cultural Rights (CESCR), reads as follows: "All peoples have the right of selfdetermination. By virtue of that right they freely determine their political status and freely pursue their economic, social and cultural development". On Article 1 CCPR see Human Rights Committee, 'General Comment No 12', adopted on 13 March 1984. Self-determination of peoples also appears in the Charter of the United Nations. See Allan Rosas, 'The Right of Self-Determination', in Eide, Asbjørn, Catarina Krause and Allan Rosas (eds), Economic, Social and Cultural Rights, 2nd edn, The Hague: Kluwer Law International, 2001, pp. 111-118, at p. 113.

116 Thomas D. Musgrave, Self Determination and National Minorities, Oxford: Oxford University Press, 1997, at p. 90 .

117 There is no universally acknowledged definition or list of criteria for a "people", in international law. See Sarah Joseph, Jenny Schultz and Melissa Castan, The International Covenant on Civil and Political Rights. Cases, Materials, and Commentary, 2nd edn, Oxford: Oxford University Press, 2004, at para. 7.06 on Article 1 CCPR.

118 The Human Rights Committee (HRC) on the one hand insists on a clear distinction between Article 1 and Article 27 CCPR, which explicitly protects minority rights. See UN, Human Rights Committee, 'General Comment 23', (UN Doc. CCPR/C/21/Rev.1/Add.5, 1994), para. 2. On the other hand, in its Concluding Observations on Canada, the HRC noted in the context of Article 1(2) CCPR that "the situation of the aboriginal peoples remains 'the most pressing human rights issue facing Canadians'" and that the right to self-determination requires "that all peoples must be able to freely dispose of their natural wealth and resources". See, UN, Human Rights Committee, 'Concluding observations of the Human Rights Committee : Canada. 07.04.1999', (UN Doc. CCPR/C/79/Add.105, 1999), para. 8.

119 In this context, one should also note the ILO Convention 169 Concerning Indigenous and Tribal Peoples in Independent Countries, adopted 27 June 1989 by the General Conference of the International Labour Organization at its seventy-sixth session, entered into force 5 September 1991, (1989) ILM 28, 1384. Article 8(2) ILO Convention 169 provides that indigenous peoples "shall have the right to retain their own customs and institutions, where these are not incompatible with internationally recognised human rights". However, the direct legal impact of ILO Convention 169 is slight, since it has been ratified by only 20 States.

120 Graber, supra note 8, pp. 26-27. 
acknowledged, Article 11(2) provides that "states shall provide redress through effective mechanisms". Moreover, Article 31 requires states to take effective measures to recognize and protect the cultural heritage, TK and TCE of indigenous peoples.

In considering the question how the concept of cultural self-determination of indigenous peoples could be implemented by governments without endangering political stability within a state, the concept of shared sovereignty appears to be helpful. This concept was introduced by Paul Chartrand, a Canadian indigenous scholar, to further the goal of reconciliation between the Aborigines and the Government in Australia. For Chartrand, shared sovereignty means that the indigenous peoples accept the de facto governance exerted by the state government over indigenous peoples while requiring at the same time that the indigenous peoples have a right to self-determination. Chartrand emphasizes that selfdetermination must not be understood in a secessionist way, but rather as the right of the indigenous peoples "to aspire to live according to their own visions of the good society, inspired by their own concepts about the universe and the values that ought to inform the way that good relations are to be established and maintained within families, communities, and the nation-state."121 The right of a people to choose its political status within a State is known in international human rights law as "internal self-determination". ${ }^{122}$ Although internal self-determination is usually given a political connotation, it also refers to the economic, social and cultural development of a people. ${ }^{123}$ If applied to issues of indigenous heritage, internal self-determination would mean recognizing the autonomous right of an indigenous people to retain control over all aspects of its heritage. ${ }^{124}$

\subsection{WHO DECIDES WHICH INDIGENOUS HERITAGE CAN BE TRADED?}

When seeking to adjust international trade law to allow indigenous peoples to participate more actively in trade in their cultural heritage without being impelled to renounce important traditional values, the difficult question is who decides which indigenous heritage can be traded and which not. If we recognize the right of an indigenous people to retain control over all aspects of its heritage, it seems selfevident to assign the competence to the heritage-owning indigenous community. Can we thus just defer to the local community's customary law for such decisions? ${ }^{125}$ According to Gunther Teubner and Andreas Fischer-Lescano, this would be a

121 Paul Chartrand, 'Reconciling Indigenous Peoples' Sovereignty and State Sovereignty', AIATSIS 2007 Conference (Canberra, 2007).

122 Joseph, Schultz and Castan, supra note 117, at paras 7.13-7.14.

123 Rosas, supra note 115, at p. 115; Joseph, Schultz and Castan, supra note 117, at para. 7.14; Federico Lenzerini, 'Sovereignty Revisited: International Law and Parallel Sovereignty of Indigenous Peoples' (2006) Texas International Law Journal, 42, pp. 155-189, at p. 165-166.

124 See Blakeney, supra note 7, at p. 125.

125 Taubman, supra note 8 , at p. 528. Determining the role of indigenous peoples' customary laws in the protection of TK and TCE is considered to be an important issue of international law. On 20 March 2007, the United Nations Permanent Forum on Indigenous Issues, appointed a Special Rapporteur charged with preparing an investigation on this topic. See UN, 'Report of the Secretariat on Indigenous Traditional Knowledge', (UN Doc. E/C.19/2007/10, 2007). 
mistake "because making reference to local customary law already means looking at holistically organized forms of society through the lens of functional differentiation and functional coding". ${ }^{126}$ Direct recourse to customary law would sometimes also create conflicts with core human rights standards (ius cogens) and international ordre public. Certain cultural or ritual practices of indigenous peoples (including honour killing, female circumcision or spearing and other physical punishment) ${ }^{127}$ must not be tolerated if we accept the primacy and universality of the international human rights standard. ${ }^{128} \mathrm{~A}$ further complication is legal certainty. From the perspective of the market, a prerequisite for trade in indigenous heritage would certainly be that third party users know what TCE may or may not be (appropriately) bought or otherwise used. ${ }^{129}$ Should transnational trade institutions thus themselves provide definitions of TK and TCE and determine what subject matter can be traded? In our view, such a solution would once again result in a subjugation of indigenous culture under Western law. As we have emphasized above, ${ }^{130}$ expressions of indigenous creativity strongly depend on the geographical, spiritual and social context of their production. ${ }^{131}$ Consequently, "the framework requirements of the respective local culture have to be maintained". ${ }^{132}$ In other words: for transnational trade institutions, it will be important to capture not only the result, but also the whole process of TCE production.

\subsection{A PROCEDURAL APPROACH TO INTERFACING GLOBAL LAW AND LOCAL TRADITIONS}

In our view, a solution for interfacing global law and local traditions should be procedural. ${ }^{133} \mathrm{~A}$ procedural approach also seems promising because several sociopsychological studies have revealed that - throughout different groups and cultures - fair procedures enhance the readiness to accept results, decisions or sentences as being just. ${ }^{134}$ What might a procedural solution look like if applied to the above-

Gunther Teubner and Andreas Fischer-Lescano, 'Cannibalizing Epistemes: Will Modern Law Protect Traditional Cultural Expressions?', in Christoph Beat Graber and Mira Burri-Nenova (eds), supra note 9, pp. 17-45, at p. 40 .

127 On spearing as an Aboriginal form of punishment, see Heather McRae, Garth Nettheim, Laura Beacroft and Luke McNamara, Indigenous Legal Issues, Commentary and Materials, 3rd edn, Sydney: Thomson, 2003, at pp. 549-551.

128 According to Article 34 DRIP, indigenous peoples must respect international human rights standards when making use of the "right to promote, develop and maintain their institutional structures and their distinctive customs, spirituality, traditions, procedures, practices".

129 Frankel, supra note 11, at p. 448.

130 See section 2.2 .

131 For Aboriginal culture in Australia the concept of "totemic polygon" has been introduced to describe the complex discursive relationship between the spiritual ancestors, the land, totemic custom and the traditional artist. For more information see Graber, supra note 17.

132 Teubner and Fischer-Lescano, supra note 126, at p. 41.

133 Similarly, Taubman, supra note 8, at p. 530, considers establishing alternative dispute resolution mechanisms to be more effective than creating new IP rights to assure effective protection of indigenous cultural knowledge.

134 Günter Bierbrauer and Edgar Klinger, 'Verfahrensgerechtigkeit/Procedural Justice', in Renate Volbert and Max Steller (eds), Handbuch der Rechtspsychologie, Göttingen etc.: Hogrefe, 2008, pp. 507-518; Tom R. Tyler, 
outlined suggestion to think about preferential rules for indigenous cultural goods (or services) originating in WTO Members that respect the rights of cultural selfdetermination and self-governance of their indigenous peoples? In our view, one such solution could consist in the development of new rules of WTO law requiring two things from a WTO Member wishing to benefit from preferential treatment. First, that this Member must opt for procedural solutions to distinguish TCE that can be traded from other TCE, and second, that such procedures respect certain standards regarding the participation of indigenous peoples in the decision-making process. In our view, such a standard should prescribe that the competent indigenous community must be involved in taking the decision on which TCE can be traded. In this respect, a likely problem would be to identify the community which owns the TCE at issue. ${ }^{135}$ With a view to providing practical guidance on resolving this problem, Erica-Irene Daes suggested several factors that should be examined. These include a community's priority in time with regard to the occupation and use of a territory, aspects of language or cultural expressions, which may show the cultural distinctiveness of the community, issues of self-identification as a distinct group and experiences of subjugation, marginalization, and dispossession, among others. ${ }^{136}$ In our view, a prima facie proof of one or more of these factors should be sufficient in order not to set the formal stakes too high for indigenous peoples. If a community can establish a prima facie case, a presumption would be raised that it is the legitimate owner of the TCE. In this case, the next step would be for the community to deliberate on the question according to its own custom and social practice and decide whether the TCE at issue can be traded. However, at this point of the interplay between local custom and international law, the law of the WTO should provide a procedural corrective to the community's decision. Accordingly, a special commission should be established within the WTO framework to formally adopt the decision. Formal adoption according to the universal rules of a transnational institution would be a guarantee that the decision is taken by the legitimate owners of the TCE and does not violate international ordre public regarding dissenting claimants. Before adopting the decision, the commission would notify the community's claim for ownership of the TCE at issue in appropriate form. If, upon such notification, a third party were to dispute the community's ownership, the third party would have to bear the burden of proof to rebut the presumption. An important question would be how this WTO commission should be composed. In our view, it would be essential for the commission to include at least a minimal number of indigenous members.

Procedures similarly regulating the interplay between modern law and traditional custom already exist at the national level in New Zealand with regard to resolving conflicts of trademark registration. According to the New Zealand Trade Marks Act, trademarks that are offensive to Maori must not be registered. ${ }^{137}$ In cases of doubt as to whether a trademark actually causes offence, the Commissioner of

Robert J. Boekmann, Heather J. Smith and Yuen J. Huo, Social Justice in a Diverse Society, Oxford: WestviewPress, 1997, pp. 75-102.

135 Blakeney, supra note 7, at p. 116; Antons, supra note 43, at p. 289.

136 Daes, as quoted in Blakeney, supra note 7, at p. 116.

137 See Section 17(b)(ii) Trade Marks Act 2002. 
Trade Marks seeks advice from a specially created Maori Advisory Committee. ${ }^{138}$ According to Frankel, to date "the Commissioner has not differed from the Committee's advice". However, such a difference would be possible if the applicant for the trademark "submits contrary advice from a different group of Maori". ${ }^{139}$

A considerable advantage of a procedural approach would be its flexibility with regard to situations of social change and when indigenous creators shift from a traditional role as a custodian of a clan's heritage towards a more modern role as artist.

\section{CONCLUSION}

The approach of law and policymaking towards the protection of indigenous creativity has generally been defensive. Only very recently, a new wave of scholarship has started to ask how indigenous peoples could make use of some of their TCE in order to spur economic development without being impelled to renounce important traditional values. The important premise of this new orientation is that indigenous peoples have the autonomous right to decide which TCE can be traded and which - because of their sacred or otherwise important meaning for a community - must not enter the market. The UN DRIP, emphasising collective rights of indigenous self-determination and self-government, including in cultural matters, fosters this novel strategy.

Adopting this new perspective, the primary question for research is no longer how misappropriation of indigenous culture could be prevented but rather how the law, and in particular international economic law, could enable indigenous peoples to participate more actively in international trade in their creative expressions. The focus of such a strategy will be on the WTO, taking account of this organization's powerful role in regulating economic globalization. However, in order to enhance regulatory coherence, interrelations with other relevant areas of international law, including human rights, intellectual property, cultural heritage and cultural property are significant. Since the rules on TCE and TK currently existing in the TRIPs Agreement and the Berne Convention are flawed, new law is necessary to provide for a level of protection that responds to the needs of indigenous peoples. Whereas negotiations on TCE and TK have been taking place in both the WIPO and TRIPS contexts, we suggest examining also, how the GATT and the GATS could be adjusted to facilitate trade in indigenous heritage. Here, a new strategy worthwhile exploring would be to devise preferential trade rules for countries respecting a standard of indigenous self-government in cultural matters, as required by the DRIP. With a view to international coherence, it will be important that this research is sufficiently coordinated with suggestions to include concerns of indigenous peoples into the implementation of Article 16 of UNESCO's Convention on Cultural Diversity.

\footnotetext{
138 Section 177 of the Trade Marks Act requires the Commissioner of Trade Marks to appoint an advisory committee to advise the Commissioner whether the registration of a trademark that is, or appears to be, derivative of Maori text and imagery, is likely to be offensive to Maori. See http://www.med.govt.nz/templates/Page___1291.aspx (accessed 27 March 09).

139 Frankel, supra note 11, at pp. 450-451.
} 
With regard to the critical question of who decides which TCE and TK can be traded and which not, a procedural solution seems to be promising. Such procedures should regulate the interplay between modern law and indigenous custom in two steps, consisting of: 1) a decision of an indigenous community on the ownership and the nature of the TK or TCE at issue; and 2) the confirmation of a specialized WTO commission that this decision does not violate legitimate rights of dissenting claimants. A procedural approach would have several advantages. First, it would respect the fact that only the TCE and TK owning community itself knows what the TCE and TK is and how far trade in these creative expressions should be permitted. Second, a procedural solution would be flexible enough to cope with the fact that indigenous culture is not static but living and thus constantly changing. When exposed to influences of globalization, indigenous communities shift from traditional to modern ways of social organization. Nonetheless, communities require autonomy in deciding how to make use of traditional creativity and how to balance collective and individual rights in their heritage. 